\title{
Diversification of the International Criminal Judiciary
}

\author{
By Tijana Surlan*
}

In this paper, the architecture of the international criminal courts is analysed. Nowadays there are several types of international criminal courts - permanent international, ad hoc international and ad hoc internationalised court. They all act at the same period of time, leaving the need for elaboration on their origins, goals, success and diversities. The main goal of this research is to reveal whether there are any kind of lawfulness when establishing concrete type of a court and whether the international community is approaching to the model of preferably one universal permanent court or several ad hoc courts established on the case-by-case basis.

Keywords: International criminal law, permanent international court, ad hoc international court, ad hoc internationalised court

\section{Introduction}

This year marks a hundred years of the term crimes against humanity. It is, much more importantly, 100 years since the tremendous massacre over million and a half of people have been commenced - massacre over Armenians, today marked as the genocide. But, what is more important for this paper is another point of view to this crime - its prosecution before an international criminal court.

Theory of International Public Law (IPL) and especially its part International Criminal Law do refer to the Nuremberg Tribunal as the first international criminal tribunal. ${ }^{1}$ It is true of course, but only if we take into account completed procedures, finalised in verdicts. On the other hand, if we try to perceive international criminal judiciary in the perspective of 100 years, other conclusion emerges. The period of the First World War, finalised in peace treaties, shows us somewhat different perspective. Peace treaties between Allied and Associated Powers on one side and for example Germany (Treaty of Versailles, 1919), Turkey (Peace Treaty of Serves, 1920), Bulgaria (Treaty of Neuilly, 1919) on the other side prescribed that special tribunals should be constituted. ${ }^{2}$ Although none of the planned tribunals was created, the intention to create them stipulated within the peace treaties does present a major shift in the system of the International Public Law. The idea that an international criminal tribunal should be constituted, with the task to prosecute

\footnotetext{
${ }^{*} \mathrm{PhD}$, Associate Professor of the International Public Law, The Academy of Criminalistic and Police Studies, Belgrade, Serbia.

${ }^{1}$ Kittichaisaree (2001) 12; Bassiouni (1980) 26

${ }^{2}$ Treaty of Versailles, 1919 - Article 227; Treaty of Sevres, 1920 - Article, 226.; Treaty of Neully, 1919 - Article 118.
} 
perpetrators of international crimes, no matter whether they are tsar, king, ministers or soldiers, was a profound novelty in the system of the IPL. Thus, this first step towards international criminal judiciary should be celebrated and remembered.

International criminal justice has not been left unsatisfied completely, though. Results of Leipzig trials are often marked as unsatisfactory. Indeed, if we compare the fact that 899 persons were accused with the fact that only 6 were found guilty, its impact could be challenged. Its legacy though is fruitful. It comprises all international criminal tribunals constituted through the 20th and 21 st century, starting with the Nuremberg Trial.

There is yet another set of prosecutions from this period that should be mentioned especially. The Armenian massacre, according to the Treaty of Sevres, should have been prosecuted before an international military tribunal. Meanwhile, Turkey has gone through the revolution and completely new political system has been introduced. The Allies were willing to support a new government with the Mustafa Kemal Ataturk as the leader, completed new peace treaty with Turkey - Treaty of Lausanne from 1923. ${ }^{1}$ The New Turkish government formed a number of military tribunals, prosecuted some of the high-level state officials for the Armenian massacre and sentenced them. Sentenced to death were Talaat Pasha, Minister of Interior, Ismail Enver Pasha, Minister of War and Ahmet Djemal Pasha, Minister of Navy. They were sentenced in absentia. ${ }^{2}$ Yet, their sentences have been completed by the Armenian Revolutionary Federation in the Operation Nemesis. ${ }^{3}$

The brief overview and recall of the genesis of the international criminal judiciary is just a prelude for the overview of fundamental changes that occurred after the Second World War. After Nuremberg and Tokyo tribunals finalised proceedings and sentenced a number of high ranking state officials, it became clear that in the future new international criminal tribunals can emerge.

It should be stressed that the genesis of the international criminal judiciary does not end by presenting only courts planned or organised by states. At the same time, throughout the whole $20^{\text {th }}$ century scholars of international law and international politics, members of pacifist movements and law associations were thinking and planning on how to create a universal criminal court. The idea was based on the successful establishment and work of international courts for state disputes. Indeed, the idea was reasonable.

Thus, through the whole period two main ideas were colliding - opting for a permanent, universal, international criminal court or ad hoc tribunals on the case by case basis.

There is still no answer to this dilemma. The end of the $20^{\text {th }}$ century brought us both types of international criminal courts. In its last decade two ad hoc tribunals were established and one permanent court. If we try to formulate

\footnotetext{
${ }^{1}$ Allies that signed the Treaty of Lausanne were British Empire, Italy, France, Japan, Greece, Romania, Kingdom of Serbs, Croats and Slovenes.

${ }^{2}$ Dadrian (1997); Hoss (2000) 208-221.

${ }^{3}$ The name for the operation has been chosen according to the Greek goddess of divine retribution.
} 
a single main, governing principle on international criminal judiciary following this pattern it would be impossible. Thus the following discussion aims to come to a conclusion on the issue - are we moving towards one permanent international criminal system or does the international community still prefer a decentralised international criminal judiciary.

\section{Contemporary International Criminal Courts Architecture}

At the moment there are one permanent international criminal court, two ad hoc international tribunals and several hybrids, mixed, internationalised criminal courts. If we focus on the chronology of their occurrence then the order would be somewhat different. First two ad hoc tribunals emerged: The International Criminal Tribunal for the former Yugoslavia (ICTY) was established in 1993, The International Criminal Tribunal for Rwanda (ICTR) in 1994. ${ }^{1}$ International Criminal Court (ICC) was established in $1998 .^{2}$ After creation of the ICC several mixed, internationalised courts emerged.

The ICTY was established by the UN Security Council resolution 827 (1993) of 25 May 1993.It is located in The Hague, the Netherlands. Its formal name is International Criminal Tribunal for the Prosecution of Persons Responsible for Serious Violations of International Humanitarian Law Committed in the Territory of the Former Yugoslavia since 1991. The foundation for its establishment was found in the incapability and avoidance of all ex-Yu states to prosecute perpetrators of international crimes. The governing principle of the international criminal policy in this particular case was that impunity was inacceptable and that the reconciliation could be achieved only through the procedure carried out by the international, impartial criminal court.

The ICTR was established by the UN Security Council resolution 955 (1994) of 8 November 1994. It is located in Arusha, Tanzania. Its formal name is International Criminal Tribunal for the Prosecution of Persons Responsible for Genocide and Other Serious Violations of International Humanitarian Law Committed in the Territory of Rwanda and Rwandan Citizens Responsible for Genocide and Other Such Violations Committed in the Territory of Neighbouring States between 1 January and 31 December 1994. While the ICTY was founded on the pure decision of the UN Security Council statemembers, establishment of the ICTR was requested by the new Rwandan government. The Government in Rwanda, founded after these violations, was aware of its incapability to deal with horrible crimes that had occurred in Rwanda. The ICTY thus presented the most acceptable pattern for the criminal prosecution of the genocide crimes. ${ }^{3}$

It should be underlined that legality of the ICTY was challenged in all ex$\mathrm{Yu}$ states and by the majority of those accused. On the other hand the ICTR did

\footnotetext{
${ }^{1}$ Schabas (2006).

${ }^{2}$ Schabas (2004).

${ }^{3}$ Herik (2005).
} 
not raise issues on legality. Such procedural weakness was important and resulted in the creation of the ICC in terms of international treaty. Its Statute has gone through the whole negotiating procedure typical for international treaties. It was adopted by a conference in Rome on 17 July 1998 and entered in force on the $1^{\text {st }}$ July 2002. The official seat of the Court is in The Hague, Netherlands, but its proceedings may take place anywhere. The ICC also maintains an office in New York and field offices in Kampala, Kinshasa, Bunia, Abéché and Bangui.

Creation of the permanent court is marked with two important facts. Primarily, the attempts to create a permanent criminal court have been deliberated for decades, since the establishment of the UN. Several commissions were organised, several versions of draft statutes have been produced with no result. Secondly, its final establishment is due to the climate created by the existence of ad hoc tribunals. Once those ad hoc international criminal courts were created it became much easier to advance permanent court and yet to leave to individual states the decision whether to ratify it. On the other hand, when speaking in terms of morality, there was no ground not to create it. At the end a court was created as an independent body, not being the part of the UN system, yet closely related to it. ${ }^{1}$

The founding idea was to create an international criminal court that would be permanent and universal. It is permanent no doubt, but is it universal? At the moment there are 123 state-parties. At the same time states such as the USA, Israel, Russia, Ukraine, China, India, Iraq, Iran, Libya, Syria, and Pakistan are missing. This is exactly the turning point - has the Court that has been created fulfilled the goals of its establishment? Do we have a universal court or not? And what is its future?

Before coming a resolution of these dilemmas it is necessary to go on with the overview of other criminal courts. Although permanent court was created, the international community -- i.e., the UN -- continued the practice of creating new arrangements for the prosecution of the most important international crimes perpetrators.

The New model was in form of mixed, hybrid criminal courts rather than a new ad hoc international court. Thus, several courts were founded.

The Special Court for Sierra Leone (SCSL) was created by the UN in January 2002. The Initiative to create a court was addressed by the Government of Sierra Leone to the UN. In the situation similar to Rwanda, the new government was aware of its incapability to prosecute those responsible for atrocities during a decade long (1991-2002) civil war. However, the arrangement with the UN turned in a different direction. In the case of Sierra Leone, the court that was created combined international and national criminal law. It combined courts staffs - judges and the office of the prosecutor -- to create mixed teams of international and national lawyers. It was decided to base the court in the country where the atrocities were committed, opposite to in sharp contrast to the pattern followed in creating previous ad hoc tribunals. The governing rationale was to prosecute perpetrators bearing the greatest

\footnotetext{
${ }^{1}$ Sadat (2008).
} 
responsibility as primarily responsible. Thus, SCSL presents a new form of an international i.e. "internationalised" criminal court. This New model of international criminal court should be more productive, faster and cheaper than ICTY and ICTY. Finally, it did come out with good results and became a residual mechanism.

The Extraordinary Chambers in the Courts of Cambodia (ECCC) is a special tribunal for Cambodia, organised as well as a hybrid internationalised court. It was established on March 2003 in cooperation between the UN and the Cambodian government with the goal to try members of the Khmer Rouge. Its genesis is quite similar to the SCSL. The initiative was addressed by The Cambodian government to the UN, with the proposal of organizing a special chamber within the legal system of Cambodia. The ground for such an agreement was found in the fact that atrocities that should have been prosecuted occurred in the period between 1975 and 1979. Agreement provided that the Chamber should consist of mixed staff members, both international and national lawyers and that it should apply both international and national law. Its task was also to prosecute perpetrators who held the most important position within the Khmer Rouge organization.

Another special tribunal was created for the specific crimes that occurred in Lebanon. Unlike the previously mentioned courts, this court has no jurisdiction over core international crimes, but its jurisdiction is limmited solely to the crime of terrorism. In fact, its primary jurisdiction is based on the one attack that occurred on 14 February 2005, when 23 persons were killed, among them Lebanese Prime Minister Hariri. Its overall jurisdiction is though expanded to other crimes connected indirectly with the 14 February attack, which were completed in the period 2004/2005. This court is titled as the Special Court for Lebanon, though its seat is in the Netherlands. The Court is, by its type, also a hybrid court, although it applies only national law. Its internationalised character could be found in the mixed staff, since the prosecutor is an international lawyer, and trial chambers consist of both international and national lawyers. The process for the establishment of the Special Tribunal for Lebanon was two fold. The first step toward the establishment of such a court was undertaken between the UN and the representatives of Lebanese government. Yet, ratification of the agreement was not accepted by the Lebanese Parliament. The court was finally established by the UN Security Council Resolution 1757 on 2007. It bears mentioning that the Resolution was adopted with 10 votes in favour and 5 abstentions - China, Qatar, Indonesia, Russia and South Africa. Legal ground for such an act was found in the Chapter VII of the UN Charter.

Thus, the Special Tribunal for Lebanon is the first court, after the ICTY, that was created by the UN Security Council Resolution, with no clear support of the state that initially had the jurisdiction over these crimes.

Specific structure of hybrid courts are chambers or panels, even courts formed in states or territories under the international administration or mission. ${ }^{1}$ Such form of hybrid courts also combines international elements in

${ }^{1}$ Nouwen (2006) 190-214. 
their work, often in the composition of chambers or in the office of the prosecutor. Such courts are for example the Special Panel for Serious Crimes for East Timor and the War Crimes Chamber in the Court of Bosnia and Herzegovina. ${ }^{1}$

As the conclusion for this part of the paper several thesis could be underlined. Primarily, there is no one predominant model for international criminal judiciary. Currently three types of courts have been recognised permanent, ad hoc and hybrid. Another terminology could be introduced as well - permanent international, ad hoc international and ad hoc internationalised. It is worth mentioning that hybrid courts are also ad hoc, not permanent courts. Nevertheless the terms hybrid, mixed or internationalised court have been accepted as term marking a combined approach, combining both international law and national law, international and national lawyers judges and prosecutors. Secondly, there is an identifiable pattern for the prevailing model. After international criminal judiciary emerged at the end of $20^{\text {th }}$ century and the very beginning of the $21^{\text {st }}$ century, ad hoc courts were chronologically first; second was the permanent court, and third were the hybrid courts. Is there a pattern, can we conclude on the prevailing model, for the future? The same question can be posed in a different manner - what is the real status of the ICC and its impact in the field of international criminal justice today?

\section{Current Status of the International Criminal Court}

It has been stated that current ICC member states consist of 123 states. That fact means that crimes committed on the territory of 123 states can be prosecuted before the ICC. It further means that even citizens of non-state parties could be brought before the ICC.

The ICC currently prosecutes 22 cases, arising from 9 situations. All of them occurred within the African continent. This fact has been the ground for severe criticism of Court's work, implying racism, discrimination and new frustrations for African states. ${ }^{2}$

Besides the mentioned cases, the ICC's Office of the Prosecutor (OTP), at the moment conducts preliminary examinations with respect to situations that occurred inAfghanistan, Georgia, Guinea, Columbia, Honduras, Korea and Nigeria. Thus, for the first time the scope of the work has been expanded to Europe, Asia, and America.

Some other information, concerning further preliminary examinations, are also important to be mentioned here. The Prosecutor Fatou Bensouda received on 10 January 2014 information alleging the responsibility of high British officials, members of armed forces, for war crimes in Iraq, in the period

\footnotetext{
${ }^{1}$ Ivanišević (2008).

${ }^{2}$ Murithi (2013); Afagbegee (2014).
} 
between 2003 and 2008. ${ }^{1}$ The dossier was presented by Public Interest Lawyers (PIL) and the European Centre for Constitutional and Human Rights (ECCHR), citing more than 400 individual cases, representing "thousands of allegations of mistreatment amounting to war crimes of torture or cruel, inhuman or degrading treatment." The Prosecutors decided to re-open a preliminary examination of the situation in Iraq. ${ }^{2}$ This decision has been welcomed by human rights activists and supporters of international criminal justice, as a step that has the potential to reaffirm the Court's role in the international community.

The previous example, although characterised as the "situation in Iraq", grounds jurisdiction on the British citizenship of the perpetrators, since United Kingdom is a member-state to the Statute of the ICC. A new investigation concerns crimes committed in Ukraine in the recent past, although this state is not a member-state to the ICC. It is worth mentioning that Ukraine signed the Rome Statute in 2000, but could not ratify it, since the Ukraine Constitutional Court found that such a treaty is incompatible with Ukraine's Constitution. Nevertheless, Ukraine showed its interest for cooperation with the ICC again, accepting its jurisdiction over alleged crimes committed in the period 21 November 2013 - 22 February $2014 .^{3}$ This period marks the Maidan Square demonstrations and the use of force by the Government of Ukraine at the pertinent time. In this instance there were no references to the stand of the Constitutional Court, neither by Ukraine representatives, nor by the Court's officials. Limited jurisdiction to a great extent communicates with the issue of compatibility. Thus, Court could not expand its jurisdiction to the overall civil war period. This is the first time that a non-state party made a self-referral, concentrating it exclusively to one person, thus leaving open wide space for speculations on the real interests of Ukraine in these potential proceedings.

Another novelty for the Court is the enrolment of a new member Palestine. Palestine formally became a member-state of the Rome Statute on 1 April 2015. In January 2015, though, it lodged a declaration accepting jurisdiction of the ICC over alleged crimes committed "in the occupied Palestinian territory, including East Jerusalem, since June 13, 2014."4 The reason for submitting the declaration at almost at the same time as ratifying the Statute is (i) rationae temporis jurisdiction of the Court and (ii) Palestinian status as a state. Previously, Palestine lodged a declaration in 2009 initiating preliminary examination. Yet, its declaration was not accepted since at that

\footnotetext{
${ }^{1}$ First information addressed to the OTP alleging war crimes by British armed forces in Iraq was not accepted. Previous Prosecutor Mr. Luis Moreno Ocampo decided not to open preliminary examination on the ground of non-sufficient gravity establishing the jurisdiction of the ICC, http://www.icc-cpi.int/NR/rdonlyres/04D143C8-19FB-466C-AB77-4CDB2FDEBEF7 /143682/OTP_letter_to_senders_re_Iraq_9_February_2006.pdf

${ }^{2}$ ICC, OTP, Statement 13/05/2014, http://www.icc-cpi.int/en_menus/icc/press\%20and\%20me dia/press\%20releases/Pages/otp-statement-iraq-13-05-2014.aspx

${ }^{3}$ ICC, Declaration by Ukraine lodged under article 12(3) of the Rome Statute, 9 April 2014, ICC-CPI-20140417-PR997,

${ }^{4}$ ICC, Declaration Accepting the Jurisdiction of the ICC, 31 December 2014, http://www.icccpi.int/iccdocs/PIDS/press/Palestine_A_12-3.pdf
} 
time Palestinian status as a state was not clear. After Palestine gained the status of non-member observer State in the UN, the ICC decided to accept its declaration and enroll Palestine as a new member-state.

Another interesting issue that has emerged before the ICC concerns atrocities committed by members of the ISIS (Islamic State of Iraq and Syria). The OTP has been informed in various forms and by various actors on different alleged international crimes. Thus, the Prosecutor issued a statement explaining that the Court does not have territorial jurisdiction over such crimes, since Iraq and Syria are not member-states. ${ }^{1}$ On the other hand, the Court can establish personal jurisdiction over ISIS members from states members of the Statue (such as Jihadi John for example) or through referral by the UN Security Council. $^{2}$ The possibility of the UN SC referral was discussed at its meeting on 27 March 2015. Meeting was initiated by the French Foreign Minister Laurent Fabius. Discussion at the meeting showed lack of consensus on (i) whether a referral should/could concern only a situation in one state or in two states (Iraq and Syria), (ii) does referral of the "situation" mean exclusively referral of a situation in a state, or (iii) can it also mean the situation itself as a general matter and even cases. ${ }^{3}$ The meeting did not provide a final stance on whether and in what form to opt for referral.

Reflecting on these novelties in the work of the ICC, several conclusions could be drawn. The first conclusion is that the ICC acts. It is recognised as a judicial forum. States as well as individuals, i.e. associations or NGO`s, do refer information to the Court. In the most general terms that suggests that the Court is accepted. At least it indicates that such a forum is needed. On the other hand, examples of declarations submitted by Ukraine and Palestine do show another trend. It shows again an eagerness to prosecute ex post facto. Such an approach is typical for ad hoc courts and and opposed to legally accurate jurisdiction pro futuro. Such a conclusion indicates that the Court still needs to uphold its presence and importance.

\section{International Criminal Courts pro futuro}

The architecture of international criminal courts is not finalised. At the moment one other court is to be created - a court dealing with war crimes that occurred at the territory of Kosovo in the period 1998/2000.

An idea to form special criminal court for crimes committed in the territory of Kosovo is as old as the United Nations Mission in Kosovo (UNMIK). The first proposal was to establish a Kosovo War and Ethnic

\footnotetext{
${ }^{1}$ ICC, OTP, Statement of the Prosecutor of the International Criminal Court, Fatou Bensouda, on the alleged crimes committed by ISIS, Statement : 08/04/2015, http://www.icc-cpi.int/en_ menus/icc/press\%20and\%20media/press\%20releases/Pages/otp-stat-08-04-2015-1.aspx

${ }^{2}$ The Prosecutor stated: "The information gathered indicates that several thousand foreign fighters have joined the ranks of ISIS in the past months alone, including significant numbers of State Party nationals from, inter alia, Tunisia, Jordan, France, the United Kingdom, Germany, Belgium, the Netherlands and Australia" - Ibid.

${ }^{3}$ UN Security Council $7419^{\text {th }}$ meeting, 27 March 2015, S/PV.7419
} 
Crimes Court, similar to the ICTY. It would have primacy over domestic courts, which would also be authorised to prosecute international crimes perpetrators. Although foundation of the court has gone through the first preparation phase, in the end it was not created. One of the reasons for such a decision was concurrent jurisdiction with the ICTY.

The need to establish a special international criminal court for the international crimes perpetrated at Kosovo, emerged once again in the period 2010 - 2014. The fact that crimes which occurred in Kosovo were not prosecuted, either by the ICTY or Kosovo courts, appeared due to the Council of Europe report, completed by Dick Marty. ${ }^{1}$ While exploring the Kosovo situation Dick Marty discovered facts on organ trafficking connected to war crimes that occurred in the territory of Kosovo and north Albania, during the period 1998-2000. ${ }^{2}$ In his findings a number of Kosovo Liberation Army (KLA) members were accused of abduction and forced organ removal. It is worth mentioning that such information was not completely new, only presented in a more detailed manner. Karla del Ponte, the former Prosecutor at the ICTY was aware of these crimes. ${ }^{3}$ Yet again, her stand was that the ICTY could not establish jurisdiction since organs were removed from human bodies in the territory of Albania, where Albania was not under the jurisdiction of the ICTY. ${ }^{4}$

Since Dick Marty`s Report did not present documents in terms of criminal investigation suitable to raise an indictment, the European Union established an autonomous investigative body based outside of Kosovo namely the Special Investigative Task Force (SITF). American investigator, though, Clint Williamson, was named as the first chief prosecutor of that EU body.

Williamson produced his report on July 2014, stating that he established enough evidence for indictments against former senior KLA officials. His findings identified an organised campaign of abduction, illegal detentions, unlawful killings and sexual violence directed mainly against Serbs and Roma mainly. Findings on forced organ removal were largely consistent with Dick Marty`s Report, but yet again there was not enough evidence to merit indictment for that crime.

The final and most important impact of Williamson`s Report is the urge to create a special court. From the period when the Report was delivered up until the present, several versions of such a future court were on the table. In the first days after Report, it was clear that such a court should be an international criminal court, probably along the lines of a hybrid international criminal court, seated outside Kosovo. Preliminary negotiations were even carried out with the Government of the Netherlands. As time passed more ideas and propositions were arising. The last version that could be heard through the media refflected

\footnotetext{
${ }^{1}$ Šurlan (2014a).

${ }^{2}$ Council of Europe, Parliamentary Assembly, Investigation of allegations of inhuman treatment of people and illicit trafficking of human organs in Kosovo, Resolution 1872, 25 January 2011.

${ }^{3}$ Ponte C. Del (2008).

${ }^{4}$ Šurlan (2014b) 67-76.
} 
the strong belief that such a court should be organised in Kosovo, applying Kosovo law. Although such a court should operate within the Kosovo justice system, it should appoint international judges and prosecutors, acquiring thus the status of a hybrid international court. EU member states such as Spain have been reluctant to endorse a court that would recognise Kosovo as a state and implement its laws because they reject Kosovo's secession. Greece, Slovakia, Romania and Cyprus also refuse to recognise Kosovo's secession from Serbia

Although there is still no such court, the Special Investigative Task Force continues to operate. On December 2011, a new chief prosecutor was appointed - David Schwendiman. His main tasks are to continue investigation and assist in the creation of the court.

\section{Conclusion}

Today the architecture of international criminal courts is quite clear. As described, international law has produced three types of international criminal courts, all of them in close relation with the United Nations. Still, future emergence and development of new courts is not clear. At this point it is important to underline that primary jurisdiction over international crimes remains with individual states. Theoretically that means that if states are properly governing their criminal justice system, there would be no need for international criminal courts. But, as history has taught us, this is not likely.

The international community is decentralised, and it plans to stay that way. If we start from that point, it is clear that the future will produce more ad hoc courts. Yet again, examples of alleged international crimes involving Ukraine, Palestine and British officials do present stimulus for belief in the ICC and its brighter future.

What is learnt from present examples? The most important message is that there is no winner in the competition for the best court model. Ad hoc hybrid courts, as the last version, did not prove to be a better solution then ad hoc tribunals. They are cheaper though and thus there is at least one clear advantage.

What is for sure is that international criminal courts are not a novelty any more. The international community is successfully struggling against impunity, and there are yet more new courts to be created. We do live in the time of strong diversification of international criminal judiciary. 


\section{References}

Afagbegee, A. (2014). The International Criminal Courts relation with Africa: An Unfair Bias?, Pan African Voices for Freedom and Justice, http://www.pambazu ka.net/en/category.php/features/91998

Bassiouni, C.M. (1980). International Criminal Law: A draft International Criminal Code, Sijthoff.

Ponte, C. Del (2008). La caccia: Io e i criminali di guerra - http://en.wikipedia.org/ wiki/The_Hunt:_Me_and_War_criminals

Dadrian, V.N. (1997). The Turkish Military Tribunal's Prosecution of the Authors of the Armenian Genocide: Four Major Court Martial Series, Holocaust Genocide Studies, Vol. 11.

Herik, L.J. van den (2005). The Contribution of the Rwanda to the Development of International Law, Martinus Nijhoff Publishers.

Hoss, A. (2000). The Trial of Perpetrators by the Turkish Military Tribunals: The Case of Yozgat, in: The Armenian Genocide - History, Politics, Ethics (ed. R. G.Hovannisian), Palgrave.

vanišević, B. (2008). The War Crimes Chamber in Bosnia and Herzegovina: From Hybrid to Domestic Court, International Center for Transitional Justice.

Kittichaisaree, K.. (2001). International Criminal Law, Oxford University Press.

Murithi, T. (2013). The African Union and the International Criminal Court: An Embattled Relationship?, Institute for Justice and Reconciliation, https://www.af ricaportal.org/dspace/articles/african-union-and-international-criminal-court-emb attled-relationship

Nouwen, S.M.H. (2006). "Hybrid courts": The hybrid category of a new type of international criminal courts, Utrecht Law Review, Vol.2, Issue 2.

Sadat, L.N.( 2008). The International Criminal court and the Transformation of International Law, in: Sadat L.N., Scharf M.P. (ed.), The Theory and Practice of International Criminal Law. Essays in Honour of M. Cherif Bassiouni, Martinus Nijhoff Publishers.

Schabas, W. A. (2004). An Introduction to the International Criminal Court, Cambridge University Press.

Schabas, W. A. (2006). The UN International Criminal Tribunals - the former Yugoslavia, Rwanda and Sierra Leone, Cambridge University Press.

Šurlan, T. (2014a). Transplantacija i trgovina ljudskim organima, tkivima i ćelijama međunarodnopravni i nacionalnopravni normativni okvir, Fondacija Centar za javno pravo, http://www.fcjp.ba/templates/ja_avian_ii_d/images/green/Tijana_ Surlan.pdf

Šurlan, T. (2014b). Oduzimanje organa kao actus reus međunarodnih krivičnih dela, Strani pravni život, No.2, pp.57-76. 
